\title{
Placement and concentration in agriculture: latest trends (case study by Russian egg poultry)
}

\author{
Olga Kostenko ${ }^{1, *}$ \\ ${ }^{1}$ Federal State Budgetary Educational Institution of Higher Education "Vyatka State Agricultural Academy," 610017, Kirov, Russia
}

\begin{abstract}
The article presents the results of research on the location and territorial concentration in agriculture. The research object is egg poultry farming, which has been one of the most stable agriculture branches in Russia for decades. The method of modified location quotients was used to analyze territorial concentration. The analysis showed that the placement of egg poultry had changed drastically in 20042019. Russian regions have employed opposed strategies. In many regions, egg poultry farms have been closed or repurposed. Several regions are successfully developing the industry, and egg production in these territories is several times higher than domestic needs. Ten regions of Russia with a location quotient higher than 2.0 were identified. The volume of interregional exchange is growing at a faster pace. In 2004, the regions exported $30 \%$ of the egg production, and by 2019 , the share increased to $51 \%$. Location specialization and optimization of egg farms provide economic and social benefits. With the growth of the size of enterprises, their financial stability increases. Cost-saving opportunities, increased egg production, and competition between producers in the domestic market help to hold prices down.
\end{abstract}

\section{Introduction}

In the coming decades, the world's demand for food will grow significantly [1]. According to the forecasts of the Food and Agriculture Organization of the United Nations [2], the world population will increase to 10 billion people by 2050 or $50 \%$ compared to 2013 .

Currently, the primary growth in food production is driven by agricultural investment and technological innovation. This is followed by an increase in the average size of enterprises and the concentration in agriculture. The scale effect was found in many studies, in Benin by the example of egg poultry farms for 20102018 [3], in Russia by the example of pig farming for 2001-2017 [4], and others.

Food systems are becoming more capital-intensive and vertically integrated, dominated by a long food supply chain. The growth in the production of agricultural raw materials and food is also achieved through specialization and new agricultural location models. Thus, in Hungary in 2000-2010, agricultural holdings' specialization increased significantly, and regions of stable poultry farming and grape growing were formed [5].

Based on specialization, intensification, and expansion, the modernization paradigm has dominated agriculture for the past decades. Specialization brings economic benefits, but as businesses grow in size, so do environmental concerns. For example, the cultivation of oil palm and rubber monocultures in Indonesia leads to land depletion and disrupts ecosystems [6].
Increasing specialization also creates employment problems for small farmers. According to the data [7] obtained in a series of studies in the European Union and Israel, farmers' specialization grew with stable markets. Now there is a pullback in favor of diversification. An alternative model of food supply to local markets is being developed - short food chains [8], creating cluster networks for knowledge exchange and cooperation.

The future of agriculture is also associated with developing organic agriculture and digital technologies $[9,10]$. This is relevant to ensure the physical availability of food and food safety, affordability, and supply stability [11]. In 2015, the UN member states adopted "The 2030 Agenda for Sustainable Development". One of its sustainable development goals is to ensure food security, improve nutrition, and promote sustainable agricultural development.

Following the new priorities, the agricultural policy of the European Union [12], China [13], and many other countries is changing. Research is underway on models for assessing the sustainability of agriculture [14] and developing methods and indicators for measuring its new parameter [15].

Russian agriculture has been developing steadily for more than ten years [16]. The Food Security Doctrine of the Russian Federation was adopted in 2010. By 2021, the domestic market is provided with the main categories of food products, and the thresholds for most key indicators (the share of domestic products) have been reached. The food imports share decreased to $25 \%$ by $2018[10]$.

\footnotetext{
* Corresponding author: kostenko ov@,vgsha.info
} 
The main growth driver in agriculture has been government support programs since 2006. An additional incentive to these processes was given by the food embargo of 2014. During this time, effective structural changes have taken place in agriculture. The share of extensive agricultural holdings in the production of products is growing, and the technical and technological renewal of production facilities continues. There are active processes of concentration, consolidation, and regional specialization. The territorial distribution of agricultural sectors is changing.

Particularly significant results were achieved in the pig and poultry industry in Russia. The development of pig farming [4] is of an intensive type. Pork production in 2019 was $113 \%$ compared to the "pre-reform" year of 1990 while the number of pigs was reduced by a third; $80 \%$ of the products are produced at large high-tech complexes.

The territorial distribution of pig farming has changed dramatically. More than half of pork production $(54 \%)$ is localized in the territory of only 11 regions of the country, where pig farming in households is almost eliminated.

Studies by the example of meat and poultry farming in Russia [17] revealed no less significant changes. First, the production of poultry meat increased significantly by 3.4 times by 1990 . Second, the structure of production has changed. More than $90 \%$ of products are now produced by commodity farms, including a large share of extensive agricultural holdings $-60 \%$. The share of households fell from $28 \%$ to $6 \%$.

The placement of meat and poultry farming is rapidly changing. The primary production is located in the European part of the country. Simultaneously, opposite changes are observed - some regions are increasing capacity and output, while others are reducing them. The level of localization of meat and poultry farming is growing, and interregional exchange is increasing.

These examples clearly illustrate the idea of new economic geography [18] about the uneven development of territories, increasing regional specialization, and regions' polarization. The authors believe that the search for optimal spatial development models should be considered a factor of economic growth, ensuring sustainable agricultural development.

A particular paradox lies in the fact that as the industry's scale effect increases, so does the production concentration at large enterprises. There comes a time when it becomes impractical to locate industry enterprises in all regions, for example, due to restrictions on markets' capacity. As a result, even if there are equally favorable conditions, some regions leave the industry, while in other regions, the industry continues to develop.

There is much research on the agricultural location by the example of various regions of the world $[3,5,7$, 19]. Russian studies are mainly conducted by the example of industry [20-22], during which agglomeration effects are detected [23]. There is almost no research on agriculture. In continuation of the authors' research on meat poultry farming, it is more interesting to analyze the location and localization of egg poultry farming.

The study aims to analyze and identify the latest trends in the territorial distribution and localization of egg poultry farming in Russia.

\section{Materials and methods}

In the study, the dialectical method, theories of regional economics, a systematic approach in economics, a review of scientific literature, and economic and statistical analysis were used.

Considering the peculiarities of statistics on agriculture, it was impossible to apply the classical formula of the location quotient, which uses indicators of the average annual number of employed only. However, agricultural statistics have indicators of agricultural production in physical terms [24]. This allows the method of modified location quotient to be used.

The modified location quotient was used, which was calculated for agricultural production in physical terms (egg production) in proportion to the average annual number of employees (hereinafter - modified location quotient) (Formula 1).

$$
\text { Local }=\frac{P V_{i} \div N E_{i}}{P V \div N E}
$$

where: Local - location quotient;

$P V i$ - egg production in the $i$-th region;

$N E i$ - average annual number of employees in the $i$-th region;

$P V$ - egg production in Russia;

$N E$ - average annual number of employees in Russia.

A high location quotient threshold of 2.0 was chosen. The data used in the calculations were taken from the official website of the Federal State Statistics Service of the Russian Federation (https://rosstat.gov.ru/).

\section{Results}

Egg poultry farming was one of the most developed branches of agriculture in Russia back in the 1980s [25]. It is highly industrialized in enterprises that widely use new technologies, means of mechanization, and automation. Its characteristic feature is a narrow specialization, the division of facilities into egg and broiler ones.

The decline in egg production in the 1990s was not as strong as in other agricultural sectors (Fig. 1). The "bottom" was in 1996 when the output fell by 33\% from 1990. Currently, egg production is approaching the volume of 1990 (97.3\% in 2019), in contrast to meat and poultry farming, where output has increased by more than 3 times over the same period. 


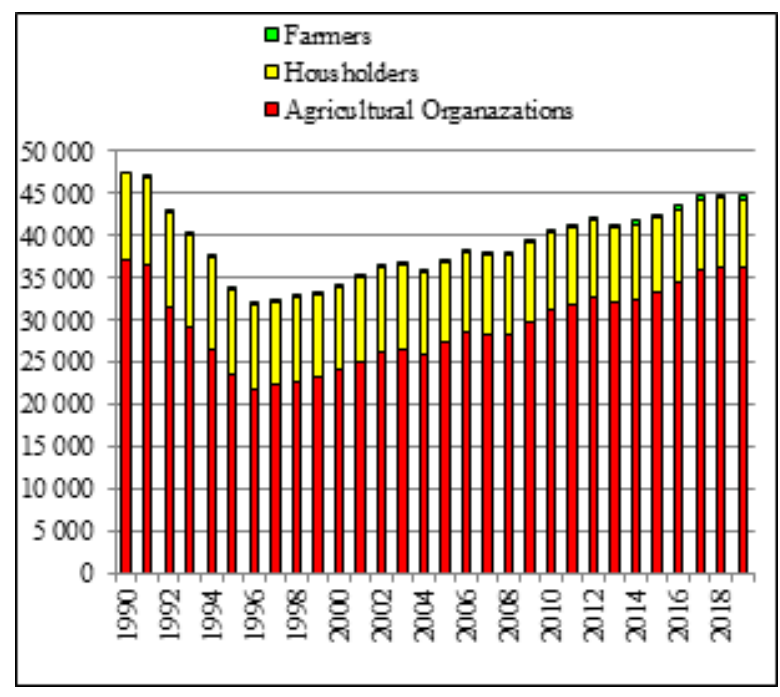

Fig. 1. Egg production in Russia is returning to the pre-reform level (data by farm categories, million pcs.).

The structure of the industry's producers is changing more slowly than in other agricultural sectors. Households still account for almost a fifth of egg production. Their share has decreased slightly over 30 years (from $21.6 \%$ in 1990 to $18.4 \%$ in 2019). For comparison, households' share in meat and poultry farming fell from $28.4 \%$ to $6.3 \%$ during this period.

Poultry farms provide a noticeable increase in output. The egg production increased by almost a third (from 236 eggs from a hen in 1990 to 311 eggs in 2019). Considering the non-commodity nature of egg production in households, the authors further use data on agricultural organizations only to analyze the commercial sector of the industry.

According to [26], the concentration in egg poultry farming increases, and the number of poultry farms is decreasing. Due to the scale effect, large poultry farms have more optimization opportunities, and their financial stability is higher.

This was followed by changes in the egg poultry location. In Russia's territory, a group of regions has formed where egg production exceeds domestic needs by several times. In the course of the study, ten regions of Russia were identified with a location quotient higher than 2.0 (Fig. 2).

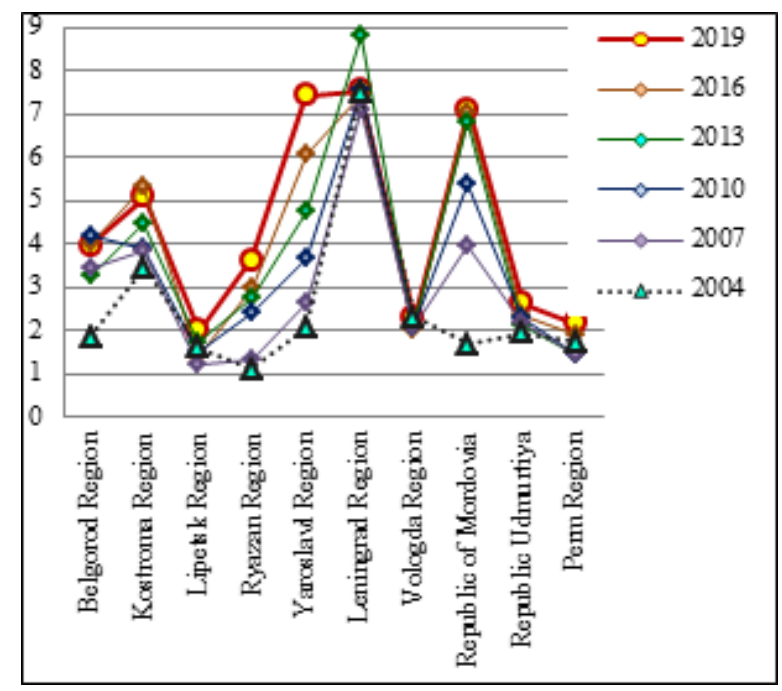

Fig. 2. Russian regions: modified location quotients above 2.0 (egg production by agricultural organizations).

These are the regions of the central part of Russia, the North-West, and the Volga Region. Poultry farms in this territory produce $45 \%$ of eggs from all-Russian production. Location quotients increased significantly compared to 2004. This is the general trend for this group of regions.

The strategy of entering the interregional markets was successfully implemented by the Yaroslavl Region, the Udmurt Republic and the Republic of Mordovia, the Ryazan and Kostroma Regions. The Belgorod Region has increased its location quotient (LQ) to 4.0 , while the region is also a leader in pig farming (LQ 20.2), meat, and poultry (LQ 13.5).

Table 1 shows the process of region formation with a high concentration of egg production over time.

Table 1. Growing localization of egg production: Russian regions with a modified location quotient above 2.0 (cells with coefficients above 2.0 are highlighted with thick frame and color), 2004-2019.

\begin{tabular}{|l|c|c|c|c|c|c|c|c|c|c|c|c|c|c|c|c|}
\hline \multicolumn{1}{|c}{ Regions } & $\mathbf{2 0 0 4}$ & $\mathbf{2 0 0 5}$ & $\mathbf{2 0 0 6}$ & $\mathbf{2 0 0 7}$ & $\mathbf{2 0 0 8}$ & $\mathbf{2 0 0 9}$ & $\mathbf{2 0 1 0}$ & $\mathbf{2 0 1 1}$ & $\mathbf{2 0 1 2}$ & $\mathbf{2 0 1 3}$ & $\mathbf{2 0 1 4}$ & $\mathbf{2 0 1 5}$ & $\mathbf{2 0 1 6}$ & $\mathbf{2 0 1 7}$ & $\mathbf{2 0 1 8}$ & $\mathbf{2 0 1 9}$ \\
\hline Belgorod Region & 1.9 & 2.3 & 3.0 & 3.4 & 4.4 & 4.0 & 4.2 & 4.1 & 3.8 & 3.2 & 3.5 & 3.9 & 4.0 & 4.1 & 4.0 & 4.0 \\
\hline Kostroma Region & 3.5 & 3.6 & 3.8 & 3.9 & 3.9 & 4.1 & 3.9 & 4.2 & 4.1 & 4.5 & 4.7 & 5.2 & 5.3 & 5.4 & 4.5 & 5.1 \\
\hline Lipetsk Region & 1.6 & 1.5 & 1.5 & 1.2 & 1.5 & 1.5 & 1.5 & 1.6 & 1.7 & 1.7 & 1.7 & 1.5 & 1.4 & 1.6 & 1.8 & 2.0 \\
\hline Ryazan Region & 1.1 & 1.1 & 1.3 & 1.3 & 1.6 & 2.1 & 2.4 & 2.6 & 2.7 & 2.8 & 2.8 & 3.1 & 3.0 & 2.7 & 3.3 & 3.6 \\
\hline Yaroslavl Region & 2.1 & 2.2 & 2.5 & 2.6 & 2.9 & 3.3 & 3.6 & 4.0 & 4.5 & 4.7 & 4.9 & 5.8 & 6.1 & 6.3 & 6.9 & 7.4 \\
\hline Leningrad Region & 7.5 & 7.2 & 7.1 & 7.1 & 7.5 & 7.6 & 7.6 & 8.2 & 8.5 & 8.8 & 8.6 & 7.8 & 7.4 & 7.9 & 7.9 & 7.5 \\
\hline Vologda Region & 2.3 & 2.4 & 2.3 & 2.1 & 1.9 & 2.1 & 2.1 & 2.1 & 2.4 & 2.1 & 1.6 & 1.8 & 2.0 & 1.8 & 1.8 & 2.3 \\
\hline Republic of Mari El & 1.6 & 1.5 & 1.7 & 1.7 & 1.7 & 1.8 & 1.8 & 1.8 & 1.7 & 1.8 & 1.8 & 2.1 & 2.0 & 2.0 & 1.9 & 1.8 \\
\hline Mordovia & 1.7 & 2.3 & 3.4 & 4.0 & 4.2 & 4.8 & 5.4 & 6.4 & 6.6 & 6.8 & 7.1 & 7.2 & 7.0 & 6.6 & 7.0 & 7.1 \\
\hline Udmurtian Republic & 1.9 & 2.0 & 2.1 & 2.2 & 2.4 & 2.4 & 2.3 & 2.1 & 2.1 & 2.1 & 2.2 & 2.3 & 2.4 & 2.5 & 2.5 & 2.6 \\
\hline Perm Region & 1.8 & 1.7 & 1.9 & 1.4 & 1.3 & 1.3 & 1.4 & 1.5 & 1.5 & 1.4 & 1.6 & 1.9 & 1.9 & 2.0 & 2.1 & 2.2 \\
\hline
\end{tabular}


Only four regions had location quotients above 2.0 in 2004. The data given in the table shows how the concentration of egg poultry farming in neighboring regions is steadily increasing, and the values of location quotients are increasing.

\section{Discussions}

As a result of the processes described above, the location of egg production has undergone powerful changes in 2004-2019. The analysis of the obtained data allows distinguishing three types of regional strategy:

- increase in egg production with export outside the region. So, the Yaroslavl Region for 15 years increased the production of eggs by 4.3 times. In the ranking of Russian regions in terms of production volumes, Yaroslavl takes the 2nd place (2.3 billion eggs in 2019), net export outside the region is $70 \%$;

- production of eggs for the regional domestic market, as well as export outside the region. The Chelyabinsk Region ranks 5th in egg production (1.5 billion eggs in 2019). For 15 years, egg production has increased by 1.5 times, export to neighboring regions of Siberia is $30 \%$;

- the region's withdrawal from egg production. The Tambov Region has reduced egg production for 15 years by 20 times. In 2019, 8 million eggs were produced, or just 20 eggs per capita per year. The strategic branch of animal husbandry in the Tambov Region is pig farming (LQ 7.3) and poultry farming (LQ 6.2).

Territorial concentration and regional specialization naturally led to faster growth of the interregional exchange. The total egg export outside the regions has increased significantly. If in 2004 the regions exported $30 \%$ of the egg production, then by $2019-51 \%$ (Fig. 3).

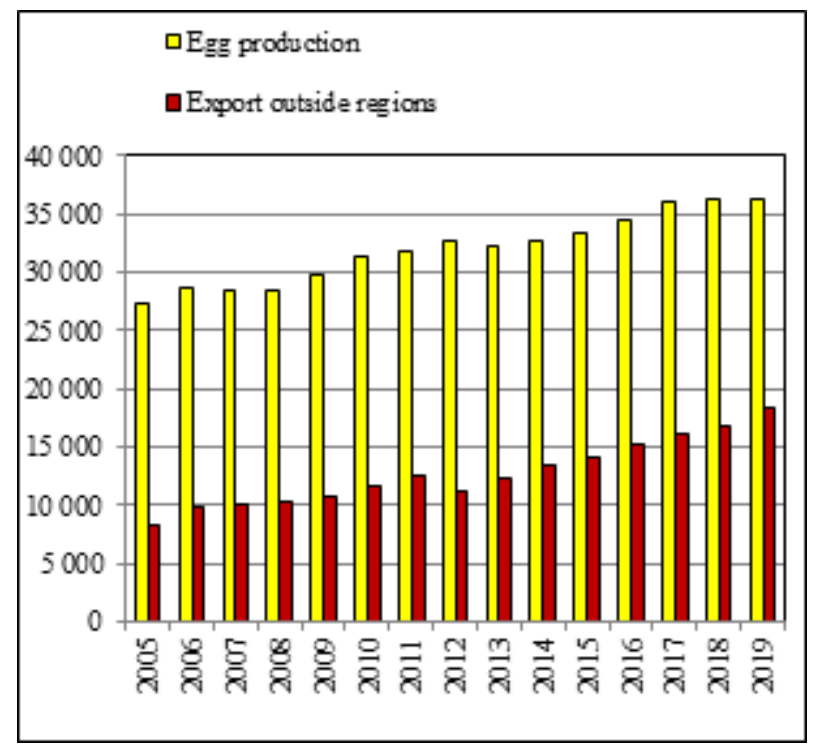

Fig. 3. Egg production and export outside regions, by agricultural organizations in Russia, million pes.

Specialization and optimization of the egg poultry farm location bring economic and social benefits. With the growth of the size of enterprises, their financial stability increases [26]. Cost-saving opportunities, increased egg production, and competition between producers in the domestic market help to hold prices down. This effect is shown by the example of three types of industries:

- the Russian pig industry has one of the highest levels of territorial concentration [4]. Average consumer prices for pork (except boneless) decreased by $3 \%$ in 2014-2019\%;

- the egg poultry industry has the average level of territorial localization, prices for chicken eggs increased by $11 \%$ over the same period;

- in dairy cattle breeding, a more uniform distribution across the country still prevails. The increase in prices for drinking milk for 5 years was $32 \%$.

\section{Conclusions}

Egg poultry farming is a high-tech branch of agriculture in Russia, where new technologies, means of mechanization, and automation are widely used.

The decline in egg production in the 1990s was not as severe as in other agricultural sectors. Currently, egg production is approaching the volume of 1990 (97.3\% in 2019).

The structure of the industry's producers is changing more slowly than in other agricultural sectors. Households still account for almost a fifth of egg production. The industry is growing in concentration, and the number of poultry farms is decreasing.

There were significant changes in the placement of egg poultry farming in 2004-2019. According to the results of the study, three types of regional strategies were identified:

- egg production strategy for export outside the region;

- egg production for the domestic market and export outside the region;

- withdrawal from egg poultry production, the conversion of poultry farms, the choice of another agricultural specialization for the region.

As a result of these processes, a group of regions has formed in Russia where egg production exceeds domestic needs by several times. Ten regions of Russia with a location quotient higher than 2.0 have been identified.

The volume of interregional exchange is growing at a faster pace. In 2004, the regions exported $30 \%$ of the egg production; by 2019 , the share increased to $51 \%$.

Specialization and optimization in egg poultry farms' location bring economic and social benefits with the growth of the size of enterprises, their financial stability increases. Cost savings, increased egg production, and competition between producers in the domestic market can help keep prices down.

\section{References}

1. M. Hunter, K. Smith, M. Schipanski, M. Atwood, D. Mortensen D. Bioscience, 67, 386-391 (2017)

2. FAO, The future of food and agriculture - Trends and challenges [Electronic resource], Rome 
(2017) Available at: http://www.fao.org/globalperspectivesstudies/resources/ru/?keywords $=92455$

3. E. Houedjofonon, A. Ahoyo, S. Chogou, D. Honfoga, G. Mensah, A. Adegbidi, Poultry Science, 99 (8), 3853-3864 (2020)

4. O.V. Kostenko, Agricultural science of the EuroNorth-East, 20 (3), 290-297 (2019)

5. Z. Andrasi, Z. Fabian, Teruleti Statisztika, 57 (4), 422-435 (2017)

6. S. Klasen, et all, Ecological Economics, 122, 111120 (2016)

7. K. Roest, P. Ferrari, R. Knickel, Journal of Rural Studies, 59, 222-231 (2018)

8. A. Kostyaev, E. Shepeleva, Agricultural science of the Euro-North-East, 20 (6), 632-644 (2019)

9. N. Nesterenko, N. Pakhomova, K. Richter, St Petersburg University Journal of Economic Studies, 36 (2), 217-242 (2020)

10. E. Krylatykh, O. Protsenko, M. Dudin, Food Policy and Security, 7 (1), 19-38 (2020)

11. R. Laurett, A. Paco, E. Mainardesa, Sustainable Production and Consumption, 27, 298-311 (2021)

12. M. Scown, M. Brady, K. Nicholas, One Earth, 3 (2), 173-175 (2020)

13. Z. Mao, Economic and Social Changes: Facts, Trends, Forecast, (2), 211-220 (2015)

14. X. Geng, D. Zhang, C. Li, Y. Li, J. Huang, X. Wang, Sustainability, 13 (1), 121 (2021)

15. N. Valizadeh, D. Hayati, Journal of Cleaner Production, 280 (1), 123797 (2021)

16. V. Uzun, N. Shagaida, Z. Lerman, Land Use Policy, 83, 475-487 (2019)

17. O.V. Kostenko, Innovative Technologies in Science and Education, E3S Web of Conf., 210, 06007 (2020)

18. P. Krugman, Journal of Political Economy, 99, 483-499 (1991)

19. T. Boeckel, W. Thanapongtharm, T. Robinson, L. D'Aietti, M. Gilbert, Agriculture, Ecosystems \& Environment, 149 (1), 144-153 (2012)

20. S. Rastvortseva, D. Ternovskii, Economic and Social Changes: Facts, Trends, Forecast, 2, 153170 (2016)

21. I. Grebenkin, Economics of Region, 16 (1), 69-83 (2020)

22. V. Antonyuk, E. Vansovich, A. Lapo, Journal of New Economy, 21 (1), 72-88 (2020)

23. O.V. Kostenko, International Conference on Efficient Production and Processing, E3S Web Conf., 161, 01008 (2020)

24. S. Rastvortseva, L. Snitko, Economic and Social Changes: Facts, Trends, Forecast, 13 (3), 46-58 (2020)

25. A. Kislyakov, Agrarian Bulletin of the Urals, 3 (95), 32-33 (2012)
26. N. Alekseeva, SPHERE, Poultry, S1, 46-49 (2017). 